\title{
Virtuous mobility: moralising vs measuring geographical mobility in Africa
}

\author{
Gordon H. Pirie \\ Department of Geography \& Environmental Studies, University of the Western Cape \\ Bellville, South Africa
}

\begin{abstract}
Mobility practices, discourse and measurement need rethinking in an age of energy shortages, environmental anxiety and virtual mobility. Standard numerical indexes and other proxies for geographical mobility can be misleading, not least in formulating public policy. The extremes of spatial mobilities in Africa may require particularly sensitive consideration; the peculiar social, psychological and economic dimensions of geographical mobility on the continent certainly need registering. Yet the exceptionalism of the African case is overdrawn and the developmentalism inherent in yearnings for more mobility is a short-term exaggeration. Revaluing totemic mechanised mobility is urgently required. The way we act on, and the way we think, talk and write about, geographical mobility needs reconceptualising in terms of fairness, equity, environmental justice, and human rights.
\end{abstract}

Key words: Africa, development indicators, human rights, inequality, mobility, transport

\section{Introduction}

Mobility studies are gaining momentum. Research is multiplying rapidly across several disciplinary fields, for example in sociology, history, geography and the representational arts. Book publishing is vigorous (see e.g. Kaufmann 2002; Vigar 2002; Thomsen et al. 2005; Cresswell 2006; Urry 2007; Canzler et al. 2008; Letherby et al. 2008; Adey 2009). Mobility is the subject of scholarly conferences, new journals and internet discussion groups. Some of these are associated with formally established mobility research centres which have a strong intellectual focus. Elsewhere, by way of 'applied' mobility studies, research clusters are forming around new mobility technologies, practices and policies in a world whose material unsustainability is no longer in doubt.

The new arch-theorisation and discourse of post-modern mobility studies is struggling to get a hearing outside academic circles: many engineers, planners and policy makers in the mobility field are likely to share frustration about impenetrable new texts (Metz 2008: 129). There is indeed a looming gap in grasping the nettle of mobility. The divide extends even further: practical scrutiny of 'new mobility', and new academic scrutiny of mobility, is firmly anchored in the global north.

At the fringe, mobility in Africa is accommodated, exercised and imagined in a 
starkly differentiated way. And mobility research continues within a conventional paradigm. This paper draws attention to divisive discrepancies in mobility in a continent where it may still be somewhat indulgent to become embroiled in the refined problematisation of mobility. This paper does, however, argue for the rethinking of mobility in some measure. Specifically, it is proposed that customary numerical yardsticks of mobility be re-examined for their appropriateness and fairness.

\section{The mobility gap}

The routines of highly mobile citizens everywhere is now self-evidently problematic. Hectic travel schedules are personally tiring; the relative privilege carries a high financial cost to funders; and there are social and environmental costs in addition. The various stresses and strains of 'hypermobility' may be the same everywhere. In Africa's case, however, the contrast with relative immobility is particularly striking. The mobility of the so-called 'kinetic elite' across and over Africa (no longer round Africa) contrasts glaringly with the immobility of masses caught in remoteness and poverty. They can but look on in amazement at the 'waBenza', a (derogatory) South African collective noun for those who travel in super-smart, black-painted luxury cars. The mobility gap may match the wide differentials of income and life chances on the continent; it is surely rooted in and expresses gaps in privilege and plenty. The condition presupposes what might be termed a 'mobility morality'.

Super-mobile people are at one end of the mobility scale. At the other extreme are Africans stranded in rural villages where mobility deprivation is acute. They are the kinetic underclass. Children walk long distances to school, making journeys which sap energy and diminish learning. The travail measures extraordinary desire and determination. Some such journeys, however, express irony and tragedy: school children walking along or across roads without pavements or lights do get knocked down and killed by reckless drivers (e.g. Cape Times, 22 November 2008; 2I April 2009). School children crammed into battered vehicles are mortality statistics in the making (the 2007/2009 'Children, Transport and Mobility in Sub-Saharan Africa' project focuses on this vulnerable group). Workers being taken home on crowded open trucks have become mortality statistics at unguarded railway crossings. Mobility can be transient indeed in places where road use is careless (Mupimpila 2008; Pelzer 2009).

Millions of rural Africans struggle to mobilise themselves to take part in civil society - to vote, worship, attend school, and participate in cultural ceremonies and festivals. Many find it difficult to afford the transport to get to a public health clinic. It has been shown that the immobility of pregnant African women in need of emergency obstetric care substantially contributes to high rates of maternal and infant mortality (see, e.g. Cham et al. 2005; see also www.mobilityandhealth.org). In December 2008, when cholera added to Zimbabwe's woes, an Agence France-Presse image of an enfeebled citizen being carted to hospital in a wheelbarrow became etched into public memory.

The distance one lives from a tar road may be as much an indicator of life chances 
as of poverty. It represents the effort involved in the first or final stage of a journey, and, in our much vaunted globalised world it is synonymous with the difficulty of connecting. Among others it is a yardstick for the isolation of farmers, and the difficulty and expense of carting crops to market (Ewisi I97I; Minten and Kyle 2002). Immobility is an obstacle to trade.

In Africa's cities, difficulties of mobility are no less apparent. Migrating to a city, however monstrous that one-off mobilisation is, is not in itself a guarantee of superior or cheaper daily mobility. Just as one can be lonely in a crowd, one can be isolated in a city. For impecunious migrants, cheap, empty land, and cheap housing, is commonly only available at the edges of metropolitan areas, often far from formal workplaces and public institutions of government, learning and health care. Journeys can be long, timeconsuming, exhausting and expensive. The sheer difficulty of getting to a job interview from a remote urban settlement creates a vicious circle of unemployment.

Whether urban or rural, geographical mobility in Africa is highly differentiated. Perhaps the separation between the 'haves' and the 'have nots' on the continent is unusual. Certainly, the hazards and experiences of geographical immobility are grinding. The trials of occasional immobility are also severe: a periodic journey can be a major financial setback. Travel can be an emotional ordeal: stories about abusive and frightening taxi use in Nairobi are cases in point (wa Mungai and Samper 2006). Occasional travel can be a life-changing ordeal: as a narrated Malawian tragedy makes plain, a journey to attend a funeral can be more raw and dramatic then ever anticipated (Kapesa 2006). Understandably, the easy mobility of privileged people is enviable. Universally, access to a private car, and then car ownership itself, has become a social and personal signifier of success and freedom. African aspirations are no different to those of others in this respect.

In a post-colonial age when Africans are no longer content to settle for second best, geographical mobility inserts itself as a condition of modernity and as an object of yearning. The desire is not to repeat the arduous mobility of the porter, the ponderous flight of the disillusioned farmer, or the slog of the itinerant pedlar, let alone the demeaning annual trek of the long-distance migrant miner (for southern Africa see Pirie I993a; 1997). On the contrary, speed and comfort are of the essence in the new journeying - in the new mobility imaginary. Most people want the thrill and terror of travel consigned to narratives about past or contemporary adventure, and to read about it second hand. The exception is trans-Africa travel by motorcar, bike and, occasionally, public transport (see e.g. Theroux 2003). Journeys such as the Paris-Dakar rally promote a view of Africa as an unencumbered playground for mobile and leisured foreigners. Participants are rarely Black Africans (but see Khumalo 2007). A 'mobility quota' for transcontinental trips has never been contemplated.

In cases where travel does become too odious, contested, and embattled, be it at a taxi rank, train station or airport, the desire to travel in greater style is not reversionary. The wish is not to become sedentary, but to move in comfort by upgrading accommodation or selecting a superior mode. Frustrated and harried travellers resort to mobility segregation if they can. 
Willingly limiting geographical mobility has scarcely ever been a personal ideal. A profound exception involves people who have been intimately affected by violence on public transport and whose reaction is to permanently avoid it. Of particular concern here is the double surrender by people who cannot buy private mobility or relocate to minimise their reliance on public transport. Estimates of the number of people killed and maimed in road 'accidents' in Africa are shocking enough: in Tanzania in 1995 there were 66 deaths for every 10,000 vehicles on the road. About I0\% $(120,000)$ of the $1.2 \mathrm{~m}$ global road deaths in 1999 occurred in sub-Saharan Africa when the region had only $4 \%$ of the world's registered road vehicles (AfDB/OECD 2005/6). One can only guess the untold numbers of traumatised passengers, spectators, relatives and friends. Statistics are scant on victims of murder, shooting, rape, assault, robbery and suicide on public transport in South Africa (Page 200I). The 83 railway coaches burned in commuter protest action in South Africa in 2005/6 is but a clinical count of damage and a pale reflection of commuter inconvenience, fear and desertion.

\section{The infrastructure gap}

For approximately two centuries, improved transport has been touted as a way of either helping Africa or having Africa help itself. The argument wears various guises: historically it has been about salvation, progress and commercialization; the familiar triptych features corridors and carriers of "commerce, Christianity and civilization" (Pirie 1982). In the more recent past it has been about nationalisation and Africanisation (see e.g. Monson 2006). Episodically, African transport has been linked with geopolitics, food wars and famine relief (Pirie I993b). In government and policy circles, and in academic debate, the argument has seldom been about conservation, whether of wilderness, culture, lifestyle or values. Refreshingly, however, questions have been asked about sensitive ecologies in road development corridors (Wilkie and Morelli I997; Wilkie et al. 2000). There is also a long-standing scepticism in African literature about egotistical road building (see e.g. Cary 1939), and about the skewed benefits of postcolonial road projects (wa Thiongo i977).

Despite reservations, improved personal mobility and improved freight circulation has long been reduced to a matter of enhancing transport services and infrastructure. The mantra among economists is better transport, better trade, better agricultural and manufacturing specialization, economies of scale, comparative advantage and enhanced wealth (see Addo 1995). In health care the links involve better roads, better circulation of foodstuffs and medicines, more food security, lower food prices, less malnutrition, better access to clinics, better inoculation. Similarly, better roads and public transport support better public administration, more effective tax collection, and so better public service, administration, education and public health delivery. And so on ad infinitum.

The economist Walter Rostow's global comparative empirical work regarded improved transport as the touchstone for economic growth (Rostow I96o; as the book's 'non-communist' subtitle implies, Rostowian ideology was about maximising wealth). On the basis of their compellingly neat work in West Africa nearly fifty years ago, three 
geographers persuaded generations to think dogmatically of African development in terms of the spatial elaboration and densification of transport networks (Taaffe et al. I963). Devising mathematical indices of route network connectivity and correlating them with indices of economic advance such as gross domestic product created a new scientific wisdom: African prosperity was associated with superior transport (see Kansky 1963). On the eve of post-colonialism in Africa, the stage was well set for deference to unrestrained mobility.

From the ig6os onwards indeed, newly elected independent governments in Africa latched onto the infrastructure imperative. Consideration of mobility was secondary, assumed to be an inevitable consequence of infrastructure provision. The dream was that roads, railways and airports would build Africa. As elsewhere, transport investment projects are very visible - even awesome - ways of 'bringing home the bacon' to a delirious, faithful and expectant electorate. Transport project symbolism was made doubly pungent by renaming motorways, streets, boulevards and airports after revolutionary heroes. Namings feature, for instance, Samora Machel, Fidel Castro and Jomo Kenyatta.

The long term record of infrastructure improvement in Africa has been disappointing. Too many transport investments have been vanity projects, serving either political or engineering egos. In some instances high cost projects were favoured over cost-effective ones due to political patronage or considerations of prestige. And expensive projects allowed for bigger financial kickbacks to corrupt officials (AfDB/OECD 2005/6: 63; Kenny 2009). Fifty years on, there are still no Pan-African highways. In total, the nine sectors of trans-Africa highway linking seven regional economic communities on the continent fall $17,000 \mathrm{~km}$ (25\%) short of the $67,000 \mathrm{~km}$ needed (AfDB/OECD 2005/6). Its vastness aside, Africa is never likely to be well connected by road: there is not enough local public money or international funding to maintain existing surfaces, let alone construct new ones (Martinez 200I). African railways are even worse with regard to interconnection. In terms of air transport, popular wisdom has it that it remains easier, cheaper and safer to fly between East and West Africa via Europe than directly through only African skies.

Even if financing, planning and implementation were to be commensurate with transport needs in Africa, war and the weather could be counted on to damage transport infrastructure. Civil wars and external aggression have taken their toll on railways in particular. ${ }^{I}$ In Angola the Benguela railway was closed for 25 years. Simmering violence in Mozambique meant that rail travel along the Nacala-Malawi corridor remained extremely dangerous and ineffective into the late ig8os (de Azvedo 2007). Severe flooding has occasionally compounded the degree of dilapidated surface transport infrastructure and throttled mobility.

In Africa there is a wide gap between visionary transport planning rhetoric and actual improvements. The disjuncture is also expressed in critical positions taken on colonial and post-colonial transport investment. Some commentators suspect the motives behind

For a first-hand account of the travails of movement across militarised southern Africa in the I9gos, see Bredin (I994). 
transport investment in the Third World, criticising the way it increases national dependency on foreign technology, on foreign energy (notably oil), and on foreign skilled labour. Foreign exchange leakages to pay for vehicles, fuel, and infrastructure expose precarious African economies to currency exchange rate fluctuations. In the worst case it might be argued that cynical foreign manufacturers and 'aid' institutions have dumped outmoded transport technology into Africa, forever condemning the continent to inferior mobility and its consequences: vehicle and service underperformance (including poor fuel efficiency, lower safety standards, unreliability and high maintenance costs).

None of this gainsays the fact that many Africans - the elite and the middle classes - have become vastly more mobile than their parents (the billions of nautical miles travelled west across the Atlantic by ro million African slaves only measure unwanted mobility of ancestors). Inter-African travel and trade is not paralysed: even in remote Cape Town, the number of foreign African shoppers and traders is conspicuously higher than a decade ago. African immigrants and refugees are more visible - and in some cases mobile enough to flee the xenophobic violence inflicted on them in October 2008. Despite evidence of improved geographical mobility, the counterfactual that Africa might have been better off without mechanised transport still makes a testing riddle: quite apart from the stance that 'improved' transport can aggravate economic misfortunes (including unemployment and deskilling) in some places, one can point to the mobility of long-distance truck drivers that became associated with the spread of the HIV/AIDS pandemic (ILOAIDS 2005). In an earlier era, railways fanned a subcontinental flu epidemic (Hogbin I985).

Transport development or extension in Africa has not always delivered the hoped for benefits. The disappointing record is reflected in the nation-based and more-orless continent-wide transport statistics used as 'development indicators' or poverty predictors. Compared to many other countries outside the continent, African countries rate poorly on measures such as length of railways and tarred roads, rates of motor vehicle ownership, aircraft traffic movements, passenger statistics, and share of rail in overall freight transport tonnage. Continental discrepancies point to yet further developmental lags (the World Bank's annual 'African Development Indicators' report includes incomplete and proximate comparative annual transport data for African countries for over 25 years; the message is weightier than the data).

Recourse to transport data as a development indicator harks back to a time when development was cast primarily as an economic concern. Linking production literally to consumption was the target in a world whose resources were considered endless. It was also germane that transport data were relatively easily and cheaply collected in the course of regular planning and operations. Nobody has ever pretended that capacitybased transport development indicators are perfect measures of actual service quality, let alone mobility. Statistics about the size of public transport fleets do not take into account fleet serviceability, or the experiences of using buses, taxis, trains and ferries. Quantifiable immobility diagnostics such as service delays, cost, congestion, predictability and geographical coverage are not generally part of a transport checklist. 
The efforts of major international transport funding agencies to design and implement more meaningful indicators of transport performance and impact so as to improve project assessment and selection are welcome. Transport information such as that gathered for and processed by the World Bank is essential for management and accounting, but it is some way from constituting a comprehensive mobility audit. Sample household travel surveys get closer to that level by measuring attributes such as household accessibility to key destinations, affordability of transport services (Olvera et al. 2008) and satisfaction with them, but high costs limit survey frequency. In South Africa's first ever such survey conducted in 2003, I,500 fieldworkers interviewed 45, 000 households (South Africa (Republic) 2005). Even in these more sophisticated data sets, the criteria nominated as benchmarks for judging acceptable service levels in such studies appear arbitrary; finding meaningful reference points for conceptualising mobility minima poses quite a challenge. Moralising mobility might assist.

\section{Mind the gaps}

On a continent short of comprehensive, continuous and comparable data, any information about transport network design capacity and use, and about performance of transport services, is seized on as a useful 'dipstick' test of personal mobility and freight circulation. But even as proxies, numerical data are mesmerising: users are easily seduced into reading them comparatively and gazing at top-end figures. The message lurking in statistical arrays is often that bigger numbers are more desirable; in this instance, more transport appears better than less transport. Countries and cities with the lengthiest route track are judged to be doing best; cities with high car registration numbers and large numbers of off-road parking places are deemed more modern; airports with the most departure gates signify some sort of transport apogee. The implication is that more mobility is better than less. Few data series drill into the hidden costs of mobility. Few expose socially skewed mobility. Few plumb its sustainability. None query the merits and limits of mobility itself.

The hidden emphasis in much transport data is also on motorised motion as the acme of transport and mobility: more boats, planes, cars and trucks appear to be a good thing; more motorways and railways too. Enumeration of non-motorised transport is, in its very nature as informal transport, much more difficult. Few people are trained to take seriously the socio-economic or environmental contributions made by (non-leisure) walking, cycling or animal traction. The lingering association of non-motorised modes with second-best mobility that is quaintly picturesque but technologically 'primitive' is hard to counter. The low-cost profile of non-motorised transport is compelling however, and its contribution to work generation, gender equality and recycling can be considerable. ${ }^{2}$ Careful attention to women's mobility and livelihoods is certainly overdue (Bryceson et al. 2003; Mandel 2004).

Indirectly, the coverage of transport news in the electronic and print media reinforces 
the view that it is the quantity and quality of motorised transport infrastructure that measures national standing and progress; that more transport is better. New road, harbour, rail and airport engineering projects command extraordinary media attention, their newsworthiness measured in proportion to the hopes and controversy they stir. Hopes centre on the notion that new capacity will ease congestion and improve the travel experience; that better enforced regulation (and road marking and lighting) will diminish traffic accidents. Transport project inaugurations and vehicle/vessel launches are celebratory affairs (except, as in the case of Cape Town's Robben Island ferry, when the intensity of media coverage was in proportion to embarrassment and fury).

Also secreted into superficial transport news reporting is the subliminal view that 'normal' transport is incident free, and without personal, social and environmental cost. By focusing on occasional flying tragedies, ocean disasters, and spectacular road traffic crashes, the media underplay continuous, small and often invisible incidents and their incremental emissions and impacts. Daily motorway congestion has become the norm and has ceased to be news. Only the most histrionic incidents of road rage are reported. Public transport delays and in-vehicle congestion are not newsworthy; they have come to be accepted simply as by-products of urban mobility. Fuel price hikes are reported as infringements on consumer choice, and the curtailment of geographical mobility - both seen as curbs on freedom or the failure of governance.

An uncritical media entrenches glorification of unencumbered fast-car mobility and even depends on doing so: motor vehicle manufacturers and private sellers account for a significant share of advertising revenue. Such as it is in Africa, the 'transport press' overwhelmingly supports motorists' interests. Motor car manufacturers persist in linking identity to make of motor vehicle: 'you are what you drive'. Motoring is further ingrained in an indistinct road lobby comprising manufacturers and insurance and motoring organisations.

The view that motorisation is key to mobilising Africa, and is essential to its competitiveness and survival, can be challenged. A gap is opening between rival conceptions of what is 'good' mobility and what are desirable and undesirable levels of mobility. Geographical mobility is no longer just assumed to be a good thing. How much mobility is necessary and how much is good for us? What degrees of mobility are affordable and sustainable? Questions need to be asked about mobility as a category, an attribute, a resource, a residue, a service, an experience, an entitlement, a value. In the starkly differentiated mobility landscape of Africa, such questions are perhaps more poignant than elsewhere. Even in the African situation of a pent up desire for increased mobility, there may be considerable dividends from restraining mobility, if not through public policy, then through social and personal lifestyle choice.

Instead of the conventional fixation with developing transport in Africa by extending motorisation, attention needs to be given to developing better appreciation of the real costs and the limits of motorised mobility on the continent. It is time to reign in the mobility imaginary in Africa, to curb expectations, and to avoid replicating Western mobility trajectories by default. The challenge is to mediate mobility more carefully and responsibly. There 
is an urgent need to extend public discourse about transport and mobility in Africa: to elevate, deepen and broaden debate. Presently, treatment of the twin subjects is marginalized and distorted. In South Africa the Mobility magazine was launched in mid-2008 to publicise transport alternatives. It will probably be a long time before it displaces motoring magazines from the display shelves of magazine retailers.

More informed journalism and better prioritisation of the issues would make clear that mobility is not just a residual condition, but that it is a set of attitudes and values. Launching a small, specialist institute to monitor mobility practices, rhetoric and reporting in Africa might serve as a training forum for a new generation of non-technicist mobility analysts and commentators (Box I). Such a laboratory might also become a seedbed for developing a mobility conscience in Africa, and a laboratory for galvanising transport activism.

Box I: An Africa mobility laboratory

Work:

- collect data on geographical mobility

- examine media coverage of transport and travel

- scrutinise the representation of transport in official and popular discourse

- expose the narrow construction of transport issues, controversies and debates

- reveal the transport and travel imaginary (and conscience) which shapes transport production and consumption

- probe the moral and political economy of transport, including notions of sustainable transport, responsible transport practices, and mobility rights

Members and associates:

- students, established scholars and transport professionals

- local and foreign transport commentators and journalists (general media and industry-specific media) upgrading their formal academic qualifications

- transport specialists in consulting firms and UN projects

- transport writers whose remit is not Africa but who can share their expertise and cultivate better standards of discourse and wiser commentary

- senior public officials and activists on sabbatical or at the end of their job/ project tenure.

Attending more seriously to mobility issues in Africa would be a timely shift away from old paradigms of progress on the continent. $n$ a new century there are fresh ways to gauge modernity; can we make walking and cycling the 'new cool' mobility practices that are affordable, sociable and sustainable? Might there come a time when low car owner- 
ship rates and the length of re-gravelled roads in African cities are regarded as a positive index of urban liveability and, indeed, of 'slowbility' - of fitness, sociability, safety and environmental quality and responsibility?

On a warming and congested planet there is evidence that the limits of mobility are in sight. People do not actively seek to spend more time each day travelling: research shows that millions of people budget a stable one hour per day to moving about in cities. Travel time savings are directed at making different journeys and/or making geographically more diverse trips that allow access to a wider spectrum of activities (Metz 2008). If this is true also in Africa, more judicious urban planning would be better than burdening the land with more mechanised transport.

\section{The rights gap}

The questions of how much geographical mobility is enough, how much there can and should be, and for whom, are open ones. In historically unequal societies such as many in Africa, there is the added question about whether or not, and if so how geographical mobility should be capped, equalised, (re)distributed - and how, immobility can be compensated. The technical measuring hurdles should not stifle the conversation. For what the question recognises is that mobility may not necessarily be an automatic entitlement, and that a person's rank in a spectrum of geographical mobility should not have to be a matter of birthright or location. In Africa of all places, there is reason to devise a new morality of mobility.

It is a priority of any mobility agenda to frame mobility in such a way that it is judicially transparent - that is amenable to judicial scrutiny (for a legal treatment in the US case see (Houseman 1979). The International Forum for Rural Transport and Development has formulated a less legalistic plea more recently). Which mobility provisions and practices might be made constitutionally 'right' and which 'wrong'? If more mobility is not necessarily better for society as a whole, for whom may it be better? Who are the most deserving 'travellers'? What mobility is excessive, unfair, unjust? What mobility rights do ordinary Africans have? Trivially, is there a way of curbing the reckless motorcade rights that politicians have appropriated; how can presidential aircraft hijacking be countered?

More pertinently, how can shocking public transport infrastructure and service in many parts of Africa be turned from a bland matter of budgetary allocation, and then managerial failure, into a question of human rights infringement? Can the persistent cumulative advantages given to car owners and users be addressed in law as an issue of social and environmental inequity? Compelling payment for the normally unaccounted for external costs of solo occupancy in motor car use would be a start. And factoring into those costs the opportunity costs of transport use would be useful: it may not be quite a zero sum game, but there are instances when affording mobility to some diminishes the mobility of others (for example, expanded private car ownership and use shrink public transport markets; bus and rail services are curtailed and then withdrawn, leaving carless people stranded). The comparative (im)mobilities concretised by apartheid urban planning into South African cities are notable instances of persistent inequalities and 
social impediments (Vanderschuren and Galaria 2003; Czeglédy 2004).

One positive step towards acting with more justice on/towards geographical mobility would be to begin formulating a mobility charter that profiles and articulates more prominently the mobility concealed in the United Nation's Millennium Development Goals. As has been noted, mobility is the 'critical catalyst' for eradicating poverty and hunger, achieving universal primary education, promoting gender equality, reducing child and maternal mortality, combating disease, and ensuring environmental sustainability (Cruczman 2003). ${ }^{3}$

A mobility charter formulated in Africa by Africans for Africans would be politically correct; its sentiments may, in the end, not differ greatly from those which might be derived differently (after all, human rights are meant to be indivisible), but its application to the extremes of continental mobility differentiation and deprivation might be distinctive (Box 2). The historic disadvantages that it sought to correct might be different too. The minimal mobility standards set might be distinctive; the costing of 'trades' between those with surplus mobility and those with deficits might be specific to Africa.

Box 2: Prospective social charter for transport and travel

A charter aiming at equality, fairness, justice and dignity in transport and travel.

It should:

- contain rights and duties (obligations) for passengers and vendors

- focus on what citizens need and deserve in accessibility and mobility

- $\quad$ seek to redress disadvantage manifest as mobility deprivation

- give special consideration to the poor, elderly, infirm, disabled to children

The charter might aim at:

- Guaranteeing a minimum standard of mobility

- Making public transport affordable to the poorest people

- Planning infrastructure and services to make public transport accessible within a specified maximum distance or walking time

- Discouraging selfish and unnecessary use of private transport

- Guaranteeing safe transport

- Protecting transport workers from abuse and attack

- Ensuring equality of opportunity in transport employment irrespective of gender, sexual orientation, race, culture \& religion

- Penalising transport users in proportion to the environmental damage, inconvenience and social disruption they cause 
The charter should target transport and travel to help achieve:

- Workable social institutions

- Economic progress, including decent livelihoods for the poorest and least able improved education and health care

- Personal opportunity, well-being, dignity and respect

- Sustainable settlements and environments

It may be naively idealistic to contemplate an operational mobility charter, but the process of wrestling with its conceptualisation may be as progressive as refining mathematical measures of geographical mobility. Indeed, the two are not mutually exclusive. One serious obstacle to attaining fair and legal mobility is the lack of objective data on individual and collective mobilities. Proving mobility denial or abuse will be key; being unable to enforce constitutional or court decisions would be fatal. Are there statistics collected easily, cheaply and regularly in the course of travel that can be used to chart 'progress' towards more sustainable and equitable geographical mobility? There are promising signs that GPS and cell phone-enabled technology can replace trip diaries and travel surveys, and can be used to monitor personal geographical mobility accurately, unobtrusively and effortlessly (Stopher et al. 2007). The applications in hard-to-reach, illiterate communities are considerable. Ethical guidelines need to be rendered clear and transparent.

\section{Conclusion}

Africa confronts mobility gaps, infrastructure gaps and juridical gaps. Some mobility gaps are anecdotal; some of them are experienced personally. Some can be measured scientifically, or at least approximated. A common response is the desire to fill these gaps - to promise, plan and provide transport links and services. But instead of filling gaps with machinery and tar, is there not a way of 'taking the gap' in Africa - of 'minding the gap' in the sense of looking after it? What about celebrating and nourishing the gap presented by levels of motorisation and congestion that lag behind those on other continents? Is there not enough reason now to inventively set about aligning mobility in Africa with social and environmental values instead of with instrumentalist positions? This is not the same as technophobia: virtual e-mobility can plug some gaps; virtuous physical mobility must do the rest.

It would be surprising if Africans had not coveted for decades the geographical mobility enjoyed by others in richer countries; asking previously underprivileged and currently disadvantaged people to deny and forego the superior accessibility that mobility affords is a bold request, even if the goal is social redress. Chasing some invisible target of environmental sustainability may not sweeten the request. Moralising car ownership and use is no small matter.

Expecting Africans to restrict their behaviour in ways that others have been unwilling to do is easily re-interpreted as an immoral reassertion of unequal power. But why 
should not Africans turn motorised mobility deficits into a virtue? The retort that discouraging motorisation means re-condemning Africans to second-class mobility is an all too easy reflex dichotomisation. After all, selectively targeted reductions in motorisation are being sought elsewhere, sometimes by re-pricing transport. Africa could set an example. Mobilising Africa by purchasing carbon credits is an irresponsible way forward. So too is hoping that driver self-interest, behaviour modification and engineering can begin to decouple mobility and mortality. Limiting the 'collateral damage' of mobility (to use the euphemism of warmongers) goes further: harming the natural environment in multiple ways is an inevitable concomitant of chasing speed and the freedom to move bodies and commodities at will.

Moralising mobility should not be construed as pathologising mobility or preaching immobility. Rather, bringing mobility into the orbit of ethics signals that geographical mobility should be considered a more precious asset whose use needs tempering. The challenge is to start contesting the purposes and practices of mobility, considering it in a more visionary way that is more relevant to the times, and to avoid lapsing into diagnoses and interventions centred on maximising mechanised mobility. Indexing and evaluating geographical mobility everywhere, most of all in Africa, should not be a mere technical exercise. There must be more to working with and on mobility than collecting better statistical data and constructing less-and-less intelligible mathematical indicators. Trimming the mobility resources consumed by the kinetic elite and diverting them to better mobilising the kinetic underclass requires political will more than science.

A well-known metaphor likens transport routes to arteries circulating essential lifeblood and oxygenating body tissue. Transport, it is said, is the pulse of cities and nations. By inference, traffic congestion is the thrombosis that immobilises and kills. But is the analogy correct for Africa? Is it not possible that in excessive doses mobility can become a contaminant whose access into the body should be limited in the first instance?

\section{References}

Addo, S. T. (I995). Accessibility, mobility and the development process. Research Review: Institute of African Studies II (I/2): I-I5.

Adey, P. (2009). Mobility. Routledge: London.

AfDB/OECD (2005/6). African Economic Outlook.

Bredin, M. (I994). Blood on the Tracks: a Rail Journey from Angola to Mozambique. Picador: London.

Bryceson, D. F., Mbara, T. C. and Maunde, D. (2003). Livelihoods, daily mobility and poverty in subsaharan Africa. Transport Reviews, 23 (2): I77-I96.

Canzler, W., Kaufmann, V. and Kesselring, S. (2008). Tracing Mobilities: Towards a Cosmopolitan Perspective. Ashgate: Abingdon.

Cary, J. W. L. (I939). Mister Johnson. Penguin: Harmondsworth.

Cham, M., Sundby, J. and Vangen, S. (2005). Maternal mortality in the rural Gambia, a qualitative study on access to emergency obstetric care. Reproductive Health 2 (3).

Cresswell, T. (2006). On the Move: Mobility in the Modern Western World. Routledge: London.

Cruczman, K. (2003). Transport - a critical catalyst. Public Service Review.

Czeglédy, A. P. (2004). Getting around town: transportation and the built environment in post-apartheid South Africa. City and Society I6 (2): 63-92. 
de Azvedo, L. (2007). The Train of Salt and Sugar. South Publishers: Johannesburg.

Ewisi, K. (I97I). Road transport facilities and their effects on local food prices in the sixties. Economic Bulletin of Ghana I (3): 24-32.

Hogbin, V. (1985). Railways, disease and health in South Africa. Social Science and Medicine 20: 933-938.

Houseman, G. K. (1979). The Right of Mobility. Kennikat: Port Washington.

Iloaids, (2005). HIV|AIDS in the Transport Sector of Southern African Countries. ILO: Geneva.

Kansky, K. J. (1963). Structure of Transportation Networks: Relationships between Network Geography and Regional Characteristics Research Paper No. 84, Department of Geography, University of Chicago.

Kapesa, F. (2006). A 'sweet' ride to Chitipa Africa Road: New Writing from Southern Africa. Spearhead: Claremont: $74-80$.

Kaufmann, V. (2002). Rethinking Mobility. Ashgate: Burlington.

Kenny, C. (2009). Transport construction, corruption and developing countries. Transport Reviews 29 (I): 2I-4I.

Khumalo, S. (2007). Dark Continent My Black Arse. Umuzi: Cape Town.

Koster, J. H. and de Langen, M. (200I). Low-Cost Mobility in African Cities. IHE: Delft.

Letherby, G. and Reynolds, G. (eds). (2008). Gendered Journeys, Mobile Emotions. Ashgate: Abingdon.

Mandel, J. L. (2004). Mobility matters: women's livelihood strategies in Porto Novo, Benin. Geography, Place and Culture II (2): 257-287.

Martinez, A. J. T. (200I). Road maintenance policies in sub-Saharan Africa: unsolved problems and acting strategies. Transport Policy 8: 257-265.

Metz, D. (2008). The Limits to Travel: How Far Will You Go? Earthscan: London.

Minten, B. and Kyle, S. (2002). The effect of distance and road quality on food collection, marketing margins, and traders' wages: evidence from the former Zaire. Journal of Development Economics 60 (2): $467-495$.

Monson, J. (2006). Defending the people's railway in the era of liberalization: TAZARA in southern Tanzania. Africa 76 (I): II3-I30.

Mupimpila, C. (2008). Aspects of road safety in Botswana. Development Southern Africa 25 (4): 424-435.

Olvera, L. D., Plat, D. and Pochet, P. (2008). Household transport expenditure in Sub-Saharan African cities: measurement and analysis. Journal of Transport Geography I6 (I): I-I3.

Page, O. (200I). Crime and Crime Prevention on Public Transport. University of South Africa Press: Pretoria.

Pelzer, K. (2009). Road use behaviour in Africa. B. E. Porter, (ed) Traffic and transportation psychology. Elsevier: Amsterdam.

Pirie, G. H. (1982). The decivilising rails: railways and underdevelopment in Southern Africa. Tijdschrift voor Economische en Sociale Geografie 73: 22I-228.

- (1993a). Railways and labour migration to the Rand mines: constraints and significance. Journal of Southern African Studies 19: 713-730.

_ (1993b). Transport, food insecurity and food aid in sub-Saharan Africa. Journal of Transport Geography I: I2-I9.

_ (1997). Brutish bombelas: trains for migrant gold miners in South Africa, c. 1900-I925. Journal of Transport History 18: 3I-44.

Rostow, W. W. (1960). The Stages of Economic Growth. Cambridge University Press: Cambridge.

South Africa (Republic) (2005). National Household Travel Survey 2003: Key Results. Department of Transport: Pretoria.

Stopher, P., FitzGerald, C. and Xu, M. (2007). Assessing the accuracy of the Sydney Household Travel Survey with GPS. Transportation 34 (6): 723-74I. 
Taaffe, E. J., Morrill, R. L. and Gould, P. R. (1963). Transport expansion in underdeveloped countries: a comparative analysis. Geographical Review 53: 503-529.

Theroux, P. (2003). Dark Star Safari: Overland from Cairo to Cape Town. Penguin: London.

Thomsen, T. U., Drewes, L. and Gudmundsson, H. (eds). (2005). Social Perspectives on Mobility. Ashgate: Abingdon.

Urry, J. (2007). Mobilities. Wiley: London.

Vanderschuren, M. J. W. A. and Galaria, S. (2003). Can the post-apartheid South African city move towards accessibility, equity and sustainablity? International Social Science Journal 55 (2): 265-277.

Vigar, G. (2002). The Politics of Mobility: Transport, the Environment and Public Policy. Spon: London.

wa Mungai, M. and Samper, D. A. (2006). "No Mercy, No Remorse": personal experience narratives about public passenger transportation in Nairobi, Kenya. Africa Today 52 (3): 5I-8I.

wa Thiongo, N. (1977). Petals of Blood. Heinemann: London.

Wilkie, D. S. and Morelli, G. A. (I997). Roads and development in eastern Congo: declining livelihoods and growing self-reliance among the Lese and Efe. Cultural Survival Quarterly 2I (3): 38-4I.

Wilkie, D. S., Shaw, E., Rotberg, F., Morelli, G. A. and Auzel, P. (2000). Roads, development and conservation in the Congo basin. Conservation Biology I4: I6I4-I622. 